\title{
Semi-dominant mutations in MFN2-related neuropathy and implications for genetic counselling
}

Pedro J Tomaselli ${ }^{1}$, Alexander M Rossor ${ }^{1}$, James M Polke ${ }^{2}$, Roy Poh ${ }^{2}$, Julian Blake ${ }^{1,3}$, Mary M Reilly $^{1}$

1. MRC Centre for Neuromuscular Diseases and National Hospital for Neurology and Neurosurgery, UCL Institute of Neurology, Queen Square, London, WC1N 3BG, UK

2. Department of Neurogenetics, The National Hospital for Neurology and Neurosurgery, UCL Institute of Neurology, London, UK.

3. Department of Clinical Neurophysiology, Norfolk and Norwich University Hospital, UK

Running title: Semi-dominant mutations in MFN2

Corresponding author: Mary M Reilly

Address: MRC Centre for Neuromuscular Diseases and National Hospital for Neurology and Neurosurgery, UCL Institute of Neurology, Queen Square, London, WC1N 3BG, UK

Telephone: 08451555000

Email: m.reilly@ucl.ac.uk 


\begin{abstract}
MFN2 is a complicated gene diagnostically. It has a large number of variants of uncertain pathogenicity and three described patterns of inheritance including dominant, semi-dominant and recessive which can cause difficulties for genetic counselling. We report a family in which two affected brothers both carried a p.R250Q and p.T362R mutation of MFN2 in trans. Both brothers developed an early onset, sensory motor neuropathy. The father, who is presumed to carry the p.R250Q mutation, died aged 63 and had no symptoms of a neuropathy. The mother who carries the p.T362R mutation has a very mild neuropathy. In both our case and that reported by Piscosquito and colleagues in this journal, these two variants appear to cause a late onset symptomatic axonal neuropathy in the heterozygous state but a more severe, early onset neuropathy in the compound heterozygous state. This raises the question as to whether clinicians should be offering routine diagnostic testing of the MFN2 gene to partners of patients with known mutations in MFN2 wishing to start a family.
\end{abstract}

Keywords: Mitofusin 2, Charcot-Marie-Tooth disease, Dominant, Semi-dominant, Recessive 


\section{Dear Editor,}

We read with interest the recent publication by Piscosquito and colleagues on mutational mechanisms in MFN2-related neuropathy in which they described a family where the proband had a severe axonal neuropathy with pyramidal signs due to a compound heterozygous mutation in MFN2 (Piscosquito, et al., 2015). One parent had a mild late onset axonal neuropathy due to a semi dominant p.R250W missense mutation and the other parent, carrying a single MFN2 null allele, was asymptomatic.

MFN2 is a complicated gene diagnostically. It has a large number of variants of uncertain pathogenicity and three described patterns of inheritance including dominant, semi-dominant and recessive which can cause difficulties for genetic counselling (Verhoeven, et al., 2006; Polke, et al., 2011; Nicholson, et al., 2008). We report a family in which two affected brothers both carried a c.749G>A, p.R250Q and c.1085C>G, p.T362R mutation of MFN2 in trans (See Table 1 for clinical details). Both brothers developed an early onset, sensory motor neuropathy. The father, who is presumed to carry the p.R250Q mutation, died aged 63 from a myocardial infarction and had no symptoms of a neuropathy. The mother who carries the p.T362R mutation has a very mild symptomatic neuropathy, diagnosed at the age of 85 with symptom onset of mild difficulty walking at age 70 . She was unable to stand on her heels or toes, sensory action potentials were absent and compound muscle action potentials significantly reduced in the lower limbs.

The elder brother presented in the first decade of life with difficulty running and poor balance. He underwent Achilles tendon lengthening surgery at the age of 10. He is now aged 53. He has length dependent weakness but with proximal involvement, requires a stick to walk and has unilateral vocal cord paralysis. Neurophysiology confirmed a length dependent sensory and 
motor neuropathy with both acute and chronic denervation on EMG in a length dependent pattern. The younger brother is less severely affected. He developed muscle cramps in his 30s. By his late 40s he reported difficulty standing. Neurological examination revealed knee bobbing and significant ankle dorsiflexion and plantar flexion weakness. Neurophysiology confirmed a length dependent sensory and motor neuropathy. Brain MRI and ophthalmic examinations were not performed in any family members.

The p.R250Q has been previously reported, however, the evidence for pathogenicity as a dominant mutation is not conclusive (Verhoeven, et al., 2006; McCorquodale, et al., 2011). In addition, it has been detected at a carrier frequency of $0.047 \%$ in European Americans by the NHLBI Exome Sequencing Project, and is listed on the ExAC database (exac.broadinstitute.org) at an allele frequency of $0.045 \%$ in non-Finnish Europeans. The p.T362R heterozygous variant has not been previously reported in the literature, though a different mutation affecting the same base p.T362M has been reported in an apparently unaffected carrier who was not examined (Polke, et al., 2011) and mildly affected individuals (Chung, et al., 2006; Nicholson, et al., 2008). Taken together this would suggest that both mutations may cause a very mild and often asymptomatic, late onset neuropathy in the heterozygous state (semi-dominant).

With the advent of next generation sequencing into routine clinical practice, counselling patients on the significance of novel MFN2 variants has become even more complicated. In both our case and that reported by Piscosquito and colleagues, two novel variants appear to cause a late onset, mild axonal neuropathy but in the compound heterozygous state cause a more severe, early onset neuropathy. This raises the question as to whether clinicians should be offering diagnostic testing of the MFN2 gene to unaffected partners of patients with known mutations in MFN2 wishing to start a family. How to interpret the significance of any MFN2 variant in the unaffected partner is 
fraught with difficulty as many semi-dominant missense mutations, like those reported in this letter, are likely to be present on variant databases such as ExaC. Both our case and that reported by Piscosquito and colleagues highlight the need for a reliable functional assay to determine the pathogenicity of novel MFN2 variants.

\section{References}

Chung KW, Kim SB, Park KD, Choi KG, Lee JH, Eun HW, Suh JS, Hwang JH, Kim WK, Seo

BC, Kim SH, Son IH, Kim SM, Sunwoo IN, Choi BO (2006). Early onset severe and late-onset mild Charcot-Marie-Tooth disease with mitofusin 2 (MFN2) mutations. Brain, 129: 2103-18.

McCorquodale DS, Montenegro G, Peguero A, Carlson N, Speziani F, Price J, Taylor SW, Melanson M, Vance JM, Züchner S (2011). Mutation screening of mitofusin 2 in Charcot-MarieTooth disease type 2. J Neurol, 258: 1234-9.

Nicholson GA, Magdelaine C, Zhu D, Grew S, Ryan MM, Sturtz F, Vallat J-M, Ouvrier RA (2008). Severe early-onset axonal neuropathy with homozygous and compound heterozygous MFN2 mutations. Neurology, 70: 1678-1681.

Piscosquito G, Saveri P, Magri S, Ciano C, Di Bella D, Milani M, Taroni F, Pareyson D (2015). Mutational mechanisms in MFN2-related neuropathy: compound heterozygosity for recessive and semidominant mutations. J Peripher Nerv Syst : doi: 10.1111/jns.12145

Polke JM, Laurá M, Pareyson D, Taroni F, Milani M, Bergamin G, Gibbons VS, Houlden H, Chamley SC, Blake J, Devile C, Sandford R, Sweeney MG, Davis MB, Reilly MM (2011). Recessive axonal Charcot-Marie-Tooth disease due to compound heterozygous mitofusin 2 mutations. Neurology, 77: 168-73. 
Verhoeven K, Claeys KG, Züchner S, Schröder JM, Weis J, Ceuterick C, Jordanova A, Nelis E, De Vriendt E, Van Hul M, Seeman P, Mazanec R, Saifi GM,Szigeti K, Mancias P, Butler IJ, Kochanski A, Ryniewicz B, De Bleecker J, Van den Bergh P, Verellen C, Van Coster R, Goemans N, Auer-Grumbach M,Robberecht W, Milic Rasic V, Nevo Y, Tournev I, Guergueltcheva V, Roelens F, Vieregge P, Vinci P, Moreno MT, Christen HJ, Shy ME, Lupski JR, Vance JM, De Jonghe P, Timmerman V (2006). MFN2 mutation distribution and genotype/phenotype correlation in Charcot-Marie-Tooth type 2. Brain, 129: 2093-2102.

Table 1. UL=Upper limbs; LL=Lower limbs; Prox=Proximal; ASIS=Anterior superior iliac spine, $\mathrm{SAP}=$ Sensory action potential; DTR=Deep tendon reflexes; $\mathrm{CMAP}=$ Compound muscular action potential; $\mathrm{Amp}=\mathrm{Amplitude} ; \mathrm{CV}=$ Conduction velocity, $\mathrm{ND}=$ Not done; $\mathrm{EDB}=$ Extensor Digitorum Brevis; CMTSS=CMT symptom score; CMTES=CMT examination score; CMTNS=CMT neuropathy score 


\begin{tabular}{|c|c|c|c|c|}
\hline \multirow{2}{*}{$\begin{array}{l}\text { Patient } \\
\text { Mutation }\end{array}$} & & 1.1 & II.1 & II. 2 \\
\hline & & T362R & $\begin{array}{c}\text { R250Q/ } \\
\text { T362R }\end{array}$ & $\begin{array}{c}\text { R250Q/ } \\
\text { T362R }\end{array}$ \\
\hline $\begin{array}{l}\text { Decade of } \\
\text { onset }\end{array}$ & & 8th & 4 th & $1 s t$ \\
\hline $\begin{array}{l}\text { Age of } \\
\text { evaluation }\end{array}$ & & 85 & 56 & 53 \\
\hline $\begin{array}{l}\text { Presenting } \\
\text { Symptom }\end{array}$ & & Poor balance & $\begin{array}{l}\text { Difficulty } \\
\text { walking }\end{array}$ & $\begin{array}{l}\text { Difficulty } \\
\text { walking }\end{array}$ \\
\hline MRC score UL & & $5 / 5$ & $5 / 5$ & $5 / 4$ \\
\hline \multicolumn{5}{|l|}{ Prox/Distal } \\
\hline \multicolumn{5}{|l|}{ Prox/Distal } \\
\hline DTR UL/LL & $\begin{array}{l}\text { UL } \\
\text { LL }\end{array}$ & $\begin{array}{l}\text { Normal } \\
\text { Absent }\end{array}$ & $\begin{array}{l}\text { Normal } \\
\text { Absent }\end{array}$ & $\begin{array}{c}\text { Reduced } \\
\text { Absent }\end{array}$ \\
\hline Pin Prick & $\begin{array}{l}\text { UL } \\
\text { LL }\end{array}$ & $\begin{array}{l}\text { Normal } \\
\text { Knee }\end{array}$ & $\begin{array}{l}\text { Normal } \\
\text { Ankle }\end{array}$ & $\begin{array}{c}\text { Normal } \\
\text { Knee }\end{array}$ \\
\hline Vibration & & $\begin{array}{l}\text { ASIS right } \\
\text { Ankle left }\end{array}$ & Normal & Normal \\
\hline Optic atrophy & & No & No & No \\
\hline CMT SS & & 5 & 3 & 7 \\
\hline CMT ES & & 11 & 9 & 19 \\
\hline CMT NS & & 11 & 9 & 23 \\
\hline \multicolumn{5}{|l|}{ SAPs } \\
\hline \multirow[t]{2}{*}{ Radial } & Amp $(\mu \mathrm{V})$ & 18 & 16 & 4 \\
\hline & $\mathrm{CV}(\mathrm{m} / \mathrm{s})$ & 55 & 61 & 64 \\
\hline \multirow[t]{2}{*}{ Median } & Amp $(\mu \mathrm{V})$ & 6 & 3 & Absent \\
\hline & $\mathrm{CV}(\mathrm{m} / \mathrm{s})$ & 48 & 52 & - \\
\hline \multirow[t]{2}{*}{ Ulnar } & $A m p(\mu \mathrm{V})$ & Absent & 1 & Absent \\
\hline & $\mathrm{CV}(\mathrm{m} / \mathrm{s})$ & - & 55 & - \\
\hline \multirow[t]{2}{*}{ Sural } & $\operatorname{Amp}(\mu \mathrm{V})$ & Absent & Absent & Absent \\
\hline & $\mathrm{CV}(\mathrm{m} / \mathrm{s})$ & - & - & - \\
\hline \multicolumn{5}{|l|}{ CMAPs } \\
\hline \multirow[t]{3}{*}{ Median } & DML (ms) & 3.8 & 3.6 & 4.0 \\
\hline & $A m p(m V)$ & 4.8 & 8.0 & 2.6 \\
\hline & $\mathrm{CV}(\mathrm{m} / \mathrm{s})$ & 53 & 50 & 52 \\
\hline \multirow[t]{3}{*}{ Ulnar } & DML (ms) & 3 & 2.6 & 3.4 \\
\hline & $A m p(m V)$ & 7.1 & 10.7 & 3.6 \\
\hline & $\mathrm{CV}(\mathrm{m} / \mathrm{s})$ & ND & 55 & 51 \\
\hline \multirow{3}{*}{$\begin{array}{l}\text { Peroneal } \\
\text { (EDB) }\end{array}$} & DML (ms) & 4.8 & Absent & Absent \\
\hline & Amp (mV) & 0.1 & - & - \\
\hline & $\mathrm{CV}(\mathrm{m} / \mathrm{s})$ & 44 & - & - \\
\hline
\end{tabular}

Table 1. 